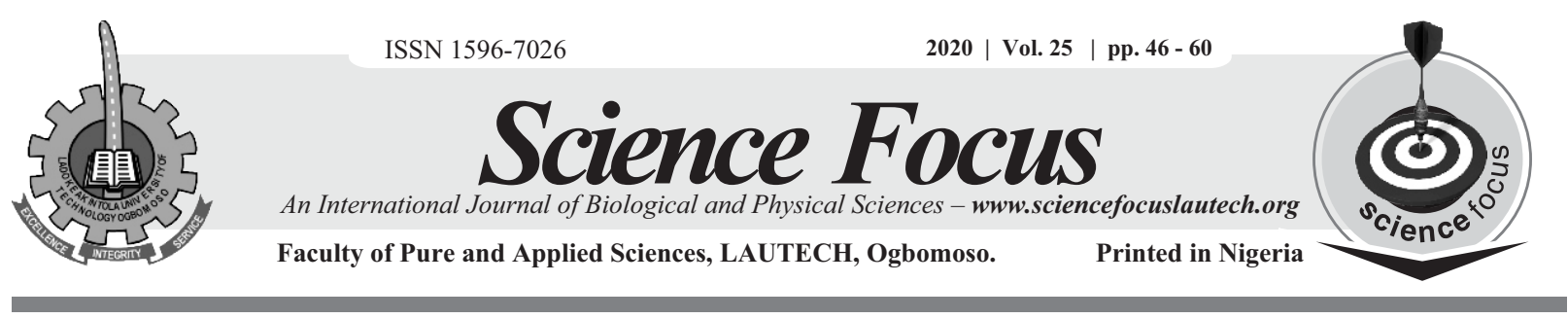

https://doi.org/10.36293/sfj.2020.0050

\title{
THERMODYNAMIC EQUILIBRIUM COMPOSITIONS FOR THE REACTIONS OF METHANE AND CARBON IN A SOLID OXIDE FUEL CELL WITH MOLTEN TIN ANODE
}

\author{
OLUSEYE OMOTOSO AGBEDE ${ }^{*},{ }^{\text {, GEOFF KELSALL }}{ }^{2}$ AND KLAUS HELLGARDT $^{2}$ \\ ${ }^{I}$ Department of Chemical Engineering, Ladoke Akintola University of Technology Ogbomoso, P.M.B. \\ 4000, Ogbomoso, Nigeria \\ ${ }^{2}$ Department of Chemical Engineering, Imperial College London, London SW7 2AZ, UK
}

\begin{abstract}
The equilibrium compositions for the reactions of methane and carbon with dissolved oxygen $\left([\mathrm{O}]_{S n}\right)$ and tin dioxide $\left(\mathrm{SnO}_{2}\right)$ in molten tin at the anode of a Solid Oxide Fuel Cell with molten tin anode ( $\mathrm{Sn}_{()^{-}}$ $S O F C)$ were investigated. The Gibbs energy minimization method and thermodynamic property data were employed in HSC Chemistry 5.1 to determine the effects of temperature, pressure and initial amounts of reactants on the equilibrium composition and to identify the predominant products at thermodynamic equilibrium and consequently the prevailing reactions for specified operating conditions. In the temperature range $973-1173 \mathrm{~K}$ and at 1 bar, the equilibrium composition for the reaction of methane with $[\mathrm{O}]_{\mathrm{Sn}}$ or $\mathrm{SnO}_{2}$ was predominantly hydrogen and carbon when $[\mathrm{O}]_{\mathrm{Sn}}$ or $\mathrm{SnO}_{2}$ was zero, mainly hydrogen and carbon monoxide (syngas) when $\left[\mathrm{O}_{\mathrm{Sn}}\right.$ : $\mathrm{CH}_{4}$ was 1:1 or $\mathrm{SnO}_{2}: \mathrm{CH}_{4}$ was 1:2, and majorly carbon dioxide and steam when $\left[\mathrm{O}_{\mathrm{Sn}}: \mathrm{CH}_{4}\right.$ was $4: 1$ or $\mathrm{SnO}_{2}: \mathrm{CH}_{4}$ was 2:1. Similarly, the equilibrium composition for the reactions of carbon with $\left[\mathrm{O}_{\mathrm{Sn}}\right.$ or $\mathrm{SnO}_{2}$ was predominantly carbon monoxide when $[\mathrm{O}]_{\mathrm{Sn}}$ : $\mathrm{C}$ was 1:1 or $\mathrm{SnO}_{2}$ : C was 1:2 but mainly carbon dioxide when $[\mathrm{O}]_{\mathrm{Sn}}$ : C was $2: 1$ or $\mathrm{SnO}_{2}: \mathrm{C}$ was 1:1, at 1 bar and $973-1173 \mathrm{~K}$. Hence, depending on the ratio $[\mathrm{O}]_{\mathrm{Sn}}: \mathrm{CH}_{4}$ or $\mathrm{SnO}_{2}: \mathrm{CH}_{4}$ at 1 bar and $973-1173 \mathrm{~K}$, the prevailing reaction of methane at a molten tin anode of an $\mathrm{Sn}_{()^{-}}$SOFC may be cracking, reforming or total oxidation while the prevailing reaction of carbon at a molten tin anode may be the partial or total oxidation depending on the ratio $[\mathrm{O}]_{\mathrm{Sn}}: \mathrm{C}$ or $\mathrm{SnO}_{2}: \mathrm{C}$ at 1 bar and $973-1173 \mathrm{~K}$.
\end{abstract}

Keywords: solid oxide fuel cell, molten metal anode, equilibrium potential difference, Gibbs energy changes

Corresponding Author Email: ooagbede@lautech.edu.ng

\section{Introduction}

Conventional power plants for electricity generation are known to have low efficiencies and high emissions of the greenhouse gas carbon dioxide which causes global warming and climate change (Beér, 2007; IPCC, 2005; Andres et al., 2011; World Energy Council, 2013). The solid oxide fuel cell (SOFC) is an energy conversion device which basically consists of a porous oxygen reducing cathode, a dense oxide ion conducting solid oxide 
electrolyte and a porous fuel oxidizing anode (Ormerod, 2003; Brett et al, 2008). SOFCs are more efficient than coal and natural gas fired power plants and produce less emissions (Beér, 2007; Song, 2002; Wu \& Wang, 2006; Giddey et al., 2012). In an SOFC, air is fed to the cathode where oxygen is reduced to oxide ion at the cathode-electrolyte interface, the oxide ion is then conducted across the electrolyte to the electrolyte-anode interface where it reacts with a fuel (e.g. hydrogen) to produce steam $\left(\mathrm{H}_{2} \mathrm{O}\right)$ and release electrons that pass through an external circuit to the cathode. The established anode of an SOFC is a cermet of nickel and yttria stabilized zirconia (Ni-YSZ) and the conventional fuel is hydrogen (Ormerod, 2003). In principle, owing to its high operating temperature of $500-1000{ }^{\circ} \mathrm{C}$, an SOFC can utilise carbonaceous fuels (e.g. coal and natural gas) in addition to hydrogen (Minh, 2004). However, there are still unresolved problems associated with the direct use of carbonaceous fuels at the Ni-YSZ anode of the SOFC which limit its performance. These include poor contact of anode with solid fuels, blockage of anode surface due to hydrocarbon cracking and subsequent carbon deposition at the anode, sintering of nickel in the Ni-YSZ anode, poisoning due to sulphur present in fuel reacting with nickel and instability due to redox cycling of nickel anode which could lead to mechanical failure of the cell (Gorte, Kim \& Vohs, 2002; Matsuzaki \& Yasuda, 2000; Kurokawa et al., 2007; Offer et al., 2009; Nikolla, Schwank \& Linic, 2009; Sarantaridis, Chater \& Atkinson, 2008).

Molten metals are currently being explored as SOFC anodes which could replace the conventional Ni-YSZ, these molten metal anodes are able to obviate the challenges encountered in the direct oxidation of carbonaceous fuels in SOFCs. Metals being considered as anodes usually have low melting points and low vapour pressures at high temperatures, they include antimony, tin, bismuth, lead, indium, copper and some alloys (Jayakumar et al., 2010; Jayakumar, Vohs \& Gorte, 2010; Tao et al., 2007; Jacob, 2011; LaBarbera, Fedkin and Lvov, 2011). Unlike the Ni-YSZ, these molten metals would not catalyse carbon formation, have relatively higher tolerance for sulphur and improved charge transfer is achievable when the SOFC is fuelled with solid carbon fuels (Tao, 2005; Tao et al., 2007; Tao et al., 2008). They are also good electronic conductors and current collection from such anodes is easier. Abernathy et al. (2011) have reported the properties and abundance of antimony, tin, bismuth, lead, indium and copper; tin stands out as a metal that is non-toxic and inexpensive, it also has a relatively low melting point and very low vapour pressure at high temperatures.

In an SOFC with molten tin anode $\left(\mathrm{Sn}_{(l)}\right.$-SOFC), oxygen reduction occurs at the cathode and oxide ions $\left(\mathrm{O}^{2-}\right)$ are conducted through the electrolyte to the electrolyte-molten metal interface where they are oxidized to oxygen atoms which dissolve in the molten tin $\left([\mathrm{O}]_{S n}\right)$. The electrons released pass through an external load to the cathode while the oxygen atoms diffuse to the molten tin-fuel interface where they react with a fuel in order to regenerate (or deoxygenate) the molten tin. The reactions in this $\mathrm{Sn}_{(l)}$-SOFC are:

Cathode:

$\mathrm{O}_{2}(g)+4 e^{-} \rightarrow 20^{2-}$

Electrolyte:

$20^{2-}$ (cathode) $\rightarrow 20^{2-}$ (anode)

Electrolyte $\mid$ tin anode interface:

$4 e^{-}+2[0]_{S n} \leftarrow 20^{2-}$

Fuel | Molten tin interface:

$[\mathrm{o}]_{S_{n}}+\mathrm{H}_{2}(g) \rightarrow \mathrm{H}_{2} \mathrm{O}(g)$

It is possible for the oxide ion to react with the molten tin at the YSZ-molten tin interface to form e.g. tin dioxide $\left(\mathrm{SnO}_{2}\right)$ depending on current densities, local mass transport rate coefficients and cell design.

YSZ-Molten tin interface:

$\mathrm{SnO}_{2}(s)+4 e^{-} \leftarrow 20^{2-}+\operatorname{Sn}(l)$

Then the fuel reaction would be with the metal oxide: 
$\mathrm{SnO}_{2}(\mathrm{~s})+2 \mathrm{H}_{2}(g) \rightarrow 2 \mathrm{H}_{2} \mathrm{O}(\mathrm{g})+\mathrm{Sn}(\mathrm{l})$

If a carbonaceous fuel e.g. methane (natural gas) is used, then the reactions with $[O]_{S n}$ may be:

$$
\begin{aligned}
& 4[\mathrm{O}]_{\mathrm{Sn}}+\mathrm{CH}_{4}(g) \rightarrow \mathrm{CO}_{2}(g)+2 \mathrm{H}_{2} \mathrm{O}(g) \\
& \text { Or } \\
& {[\mathrm{O}]_{S_{n}}+\mathrm{CH}_{4}(g) \rightarrow \mathrm{CO}(g)+2 \mathrm{H}_{2}(g)}
\end{aligned}
$$

Likewise, the reaction of methane with $\mathrm{SnO}_{2}$ may be:

$$
\begin{aligned}
& 2 \mathrm{SnO}_{2}(\mathrm{~s})+\mathrm{CH}_{4}(g) \rightarrow \mathrm{CO}_{2}(g)+2 \mathrm{H}_{2} \mathrm{O}(g)+ \\
& 2 \mathrm{Sn}(\mathrm{l})
\end{aligned}
$$

or

$$
\begin{aligned}
& \mathrm{SnO}_{2}(\mathrm{~s})+2 \mathrm{CH}_{4}(g) \rightarrow 2 \mathrm{CO}(g)+4 \mathrm{H}_{2}(g)+ \\
& \mathrm{Sn}(\mathrm{l})
\end{aligned}
$$

Reactions [8] and [10] suggest the possible reforming of methane to synthesis gas (carbon monoxide and hydrogen), also known as syngas at the molten tin anode. These reactions are of high importance because syngas is used as feed in Fischer-Tropsch synthesis of higher hydrocarbons (Van der Laan \& Beenackers, 1999), methanol or dimethyl ether (DME) synthesis (Lunsford, 2000), high temperature fuel cells (Song, 2002) and production of other high value chemicals. Syngas also yields hydrogen for various uses, including ammonia production by the Haber process, petroleum processing, petrochemical production, oil and fat hydrogenation, and as a fuel in fuel cells and aerospace industry (Ramachandran \& Menon, 1998; Van der Laan \& Beenackers, 1999; Holladay et al., 2009).

Similarly, the reactions of carbon with $[0]_{S n}$ or $\mathrm{SnO}_{2}$ may produce $\mathrm{CO}_{2}$ or $\mathrm{CO}$ :

$$
\begin{aligned}
& 2[O]_{S n}+C(s) \rightarrow \mathrm{CO}_{2}(g) \\
& {[O]_{S_{n}}+C(s) \rightarrow \mathrm{CO}(g)} \\
& \mathrm{SnO}_{2}(s)+C(s) \rightarrow \mathrm{CO}_{2}(g)+\mathrm{Sn}(l) \\
& \mathrm{SnO}_{2}(\mathrm{~s})+2 \mathrm{C}(\mathrm{s}) \rightarrow 2 \mathrm{CO}(g)+\mathrm{Sn}(\mathrm{l})
\end{aligned}
$$

Unlike conventional power plants, the $\mathrm{CO}_{2}$ produced in a $\mathrm{Sn}_{(())}$-SOFC may be easily captured and sequestered.

The equilibrium composition of a chemical reaction at a particular operating condition of e.g. temperature, pressure and amount of reactants reveals the prevailing reaction(s) at such condition and the condition under which a desired chemical product may be obtained. It is essential to determine the operating conditions at which useful chemical or fuel (e.g. syngas) may be produced with an appreciable yield (in addition to the generation of electricity) at the molten tin anode of a $\mathrm{Sn}_{(l)}$-SOFC, the other products that might be formed along with it and the relative amount of these other products. Hence, this study investigated the thermodynamic equilibrium compositions of the reactions of carbon and methane with dissolved oxygen (or tin dioxide) in molten tin at the molten tin anode of a $\mathrm{Sn}_{(l)}$-SOFC. It employed thermodynamic properties to predict the operating conditions of temperature, pressure and initial amounts of reactants under which desirable products e.g. carbon monoxide or syngas may be produced in addition to electricity generation in a $\mathrm{Sn}_{(l)}$-SOFC fuelled with carbon or methane, respectively.

\section{Methodology}

In this study, the Gibbs energy minimization method for the computation of multicomponent equilibrium composition in heterogeneous systems was employed in HSC Chemistry 5.1 for the computation of equilibrium compositions of potential multicomponent heterogeneous reactions of a $\mathrm{Sn}_{(l)}$-SOFC fuelled with carbon or methane. It involves the adjustment of species concentration by the LaGrange multiplier method until the Gibbs energy of equation [15] reaches a minimum value (equation 16) at equilibrium subject to the atom balance constraints at the specified pressure and temperature (Annamalai \& Puri, 2002).

$$
\begin{aligned}
& G=G\left(T, P, n_{1}, n_{2}, \ldots \ldots \ldots, n_{i}\right) \\
& d G_{T, P}=0
\end{aligned}
$$


An atom balance is formulated for each element $j$ in the species:

$$
\sum_{1}^{N} a_{j i} n_{i}=b_{j} j j=1, \ldots \ldots, M
$$

Where $a_{j i}$ denotes the number of atoms of an element $j$ in species $i, b_{j}$ number of $j$ atoms entering the reactor, $n_{i}$ number of moles of species $i$ while $\mathrm{M}$ and $\mathrm{N}$ are the numbers of elements and species in the system, respectively. This relation can be expressed using the Lagrange multiplier method:

$$
\lambda_{j}\left(\sum_{1}^{N} a_{j i} n_{i}-b_{j}\right)_{j=1, \ldots, M}
$$

Where $\lambda_{j}, \quad j=1, \ldots \ldots, M$, are Lagrangian multiplier. The Gibbs energy is minimized subject to the condition of equation [18] so the function of equation [19] is created:

$$
L=G+\sum_{1}^{M} \lambda_{j}\left(\sum_{i}^{N} a_{j i} n_{i}-b_{j}\right), j=1, \ldots \ldots, M
$$

So:

$$
\frac{\partial L}{d n_{i}}=\left(\frac{\partial G}{\partial n_{i}}\right)_{T, p}+\left(\Sigma_{1}^{M} \lambda_{j} a_{j i}\right)_{T, p}=0 i=
$$

$1, \ldots . . . . N$

The minimization of function $L$ with respect to $n_{i}$ for each of the species yield:

$$
\mu_{i}+\sum_{1}^{M} \lambda_{j} a_{j i}=0 i=1, \ldots \ldots N
$$

For an ideal mixture of gases or ideal mixture of liquids or solids:

$$
\mu_{i}=\Delta G_{i}^{o}(T, P)+R T \operatorname{In}\left(X_{i}\right)
$$

Where $\mu_{i}$ is the chemical potential, $\Delta G_{i}^{\circ}$ the standard Gibbs energy change for the formation of species $i$ and $X_{i}$ the mole fraction of species $i$.
The Gibbs energy for a species is calculated from its enthalpy $\left(H_{i}\right)$ and entropy $\left(S_{i}\right)$ :

$$
G_{i}=H_{i}+T S_{i}
$$

where

$$
\begin{aligned}
& H_{i}=H_{i, 298,15}^{o}+\int_{298: 15}^{T} C_{p, i}(T) d T \\
& S_{i}=S_{i, 298: 15}^{o}+\int_{298,15}^{T} \frac{c_{p i}(T)}{T} d T
\end{aligned}
$$

$H_{i, 298,15}^{\circ}$ and $S_{i, 298,15}^{\circ}$ are the standard enthalpy and entropy of formation of the species, respectively and $C_{p, i}$ is heat capacity at constant pressure. If there is a change of phase equations [26] and [27] are used instead of [24] and [25]:

$$
\begin{aligned}
& H_{i}=H_{i, 298,15}^{\circ}+\int_{298,15}^{T_{p c i}} C_{p, i}(T) d T+H_{p c, i}+ \\
& \int_{T_{p e, i} i}^{T} C_{p, i}(T) d T
\end{aligned}
$$

$$
\begin{aligned}
& S_{i}=S_{i, 298,15}^{o}+\int_{298,15}^{T_{p c_{i} i}} \frac{c_{p i i}(T)}{T} d T+\frac{H_{p c_{,} i}}{T_{p c_{i} i}}+ \\
& \int_{T_{p c_{i} i}}^{T} \frac{c_{p i i}(T)}{T} d T
\end{aligned}
$$

where $T_{\epsilon p_{i} i}$ is the temperature at which a change of phase occurs while $H_{p c, i}$ is the enthalpy of phase change of the species.

The temperature dependence of $C p\left(\mathrm{~J} \mathrm{~mol}^{-1} \mathrm{~K}^{-1}\right)$ is given as:

$C_{p}(T)=A+B * 10^{-3} T+C * 10^{5} T^{-2}+D *$ $10^{-6} T^{2}$

The Gibbs equilibrium solver in HSC Chemistry 5.1 solved these equations to obtain the amount of each species at specified operating conditions of temperature, pressure and initial amount of reactants. The thermodynamic property data (constants A, B, C, and D as well as the standard 
enthalpies and entropies of formation of species) used for the computation of the Gibbs energy changes for the formation of species considered in this study were obtained from Barin, Knacke \& Kubaschewski, 1977; Barin, 1993; Chase et al., 1985; Frenkel et al., 1994; Gurvich, Veitz, \& Alcock, 1989; Glushko, 1994; Knacke, Kubaschewski \& Hesselman, 1991; Landolt, 1999; McBride, Gordon \& Reno (1993); and Otsuka, Sano \& Kozuka, 1981, Binnewies \& Milke (2002), and Parnaik (2003).

The reaction system with its phases, species (both reactants and products), amounts of reactants and temperatures were specified while the program computed the quantities of products at equilibrium in isobaric and isothermal conditions. Stoichiometric amounts of reactants (fuel and oxidants) for the formation of desirable products e.g. carbon monoxide for the partial oxidation of carbon, carbon dioxide for complete oxidation of carbon, carbon dioxide and steam for complete oxidation of methane, and carbon monoxide and hydrogen for methane reforming were used. The effect of temperature on equilibrium composition was determined at a constant pressure of $1 \mathrm{bar}$, effect of pressure at a constant temperature of $800{ }^{\circ} \mathrm{C}$, and the effect of initial amount of reactant at a constant pressure and temperature of 1 bar and $800{ }^{\circ} \mathrm{C}$, respectively.

The results of the computations are shown as plots of equilibrium amount ( $\mathrm{kmol})$ versus absolute temperature $(\mathrm{K})$, or pressure (bar) or initial amount of reactant $(\mathrm{kmol})$ as the case may be. The quantity of the molten tin used was far larger than the amounts of the fuels and oxidants; this was to take into consideration a reaction system which involves a large amount of molten tin in a reactor. Consequently, the variations in the amounts of tin were not shown on the graphs because they made other species' variations inconspicuous.

\section{Results and Discussion}

\section{Equilibrium Compositions for $[\mathrm{O}]_{S n}$ Reactions with Methane and Carbon}

Figure 1 shows the effect of the initial amount of dissolved oxygen in molten tin on equilibrium composition for the reaction of $0.1 \mathrm{kmol}$ of methane with dissolved oxygen in molten tin at $1 \mathrm{bar}$ and $800{ }^{\circ} \mathrm{C}$. At near-zero concentration of dissolved oxygen, the reaction was essentially the cracking of methane to carbon and hydrogen, but as the oxygen concentration increased carbon monoxide was formed along with hydrogen and minute quantities of carbon dioxide and steam while the amount of carbon decreased. The amount of carbon monoxide reached a maximum when the ratio of the reactants $[\mathrm{O}]_{S_{n}: \mathrm{CH}_{4}}$ was about $1: 1$, and the prevailing reaction at this condition was the partial oxidation (reforming) of methane to syngas. Beyond this concentration, the amounts of $\mathrm{CO}$ and $\mathrm{H}_{2}$ decreased with increasing amount of dissolved oxygen while the amounts of steam and carbon dioxide increased and were at a maximum at $[\mathrm{O}]_{\mathrm{Sn}_{n}}: \mathrm{CH}_{4}$ of $4: 1$. Thus the prevailing reaction when the ratio $[\mathrm{O}]_{S_{n}}: \mathrm{CH}_{4}$ was $4: 1$ was the total oxidation of methane. Tin dioxide began to form at a $[\mathrm{O}]_{S_{n}}: \mathrm{CH}_{4}$ ratio higher than 3:1.

Hence, subsequent results show the effects of temperature at constant pressure of $1 \mathrm{bar}$ and the effects of pressure at constant temperature of $800{ }^{\circ} \mathrm{C}$ for the three possible prevailing conditions of methane cracking, reforming and total oxidation. The effects of temperature and pressure on the equilibrium compositions for methane cracking were determined by specifying zero for the dissolved oxygen amount in the molten tin, while the ratio $[O]_{S_{n}}: \mathrm{CH}_{4}$ of 1:1 and $4: 1$ were used for the reforming and total oxidation reactions, respectively. 


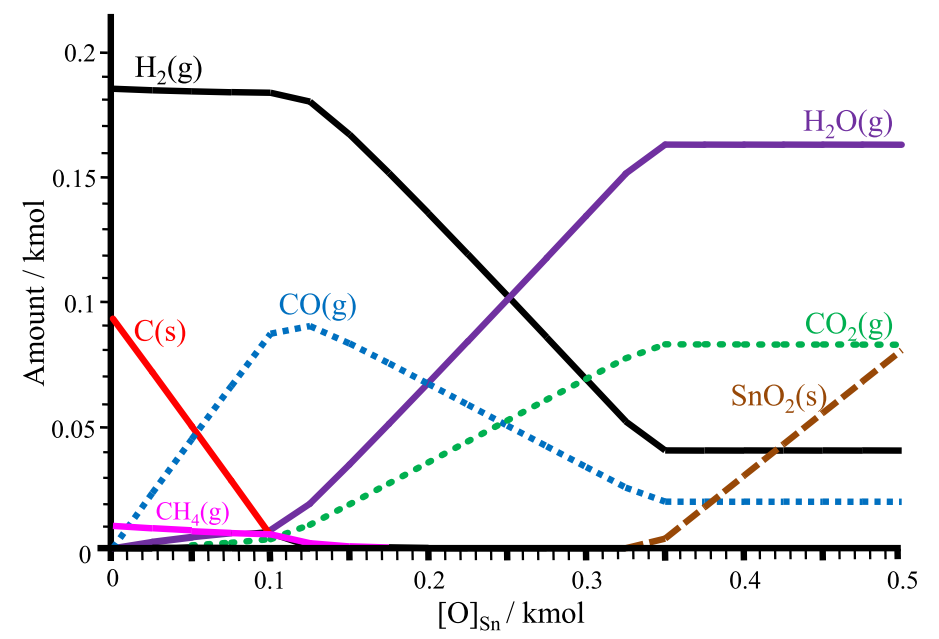

Figure 1: Effect of initial amount of dissolved oxygen in molten tin on the equilibrium composition for the reaction of $\mathrm{CH}_{4}$ with $[\mathrm{O}]_{S n}$ at 1 bar and $800{ }^{\circ} \mathrm{C}$.

Figure 2a shows that if methane is for instance bubbled through molten tin in the absence of dissolved oxygen there is the cracking of the methane. The amounts of the cracking products increased while the amount of the un-reacted methane decreased with increasing temperature in the range $973-1273 \mathrm{~K}$ investigated. Figure $2 \mathrm{~b}$ shows the effect of pressure on the cracking of methane at molten tin interface, the amounts of hydrogen and carbon decreased with increasing pressure. Thus in the absence of dissolved oxygen in molten tin, methane cracking could take place at the molten tin interface and this reaction is favoured by high temperature and low pressure.
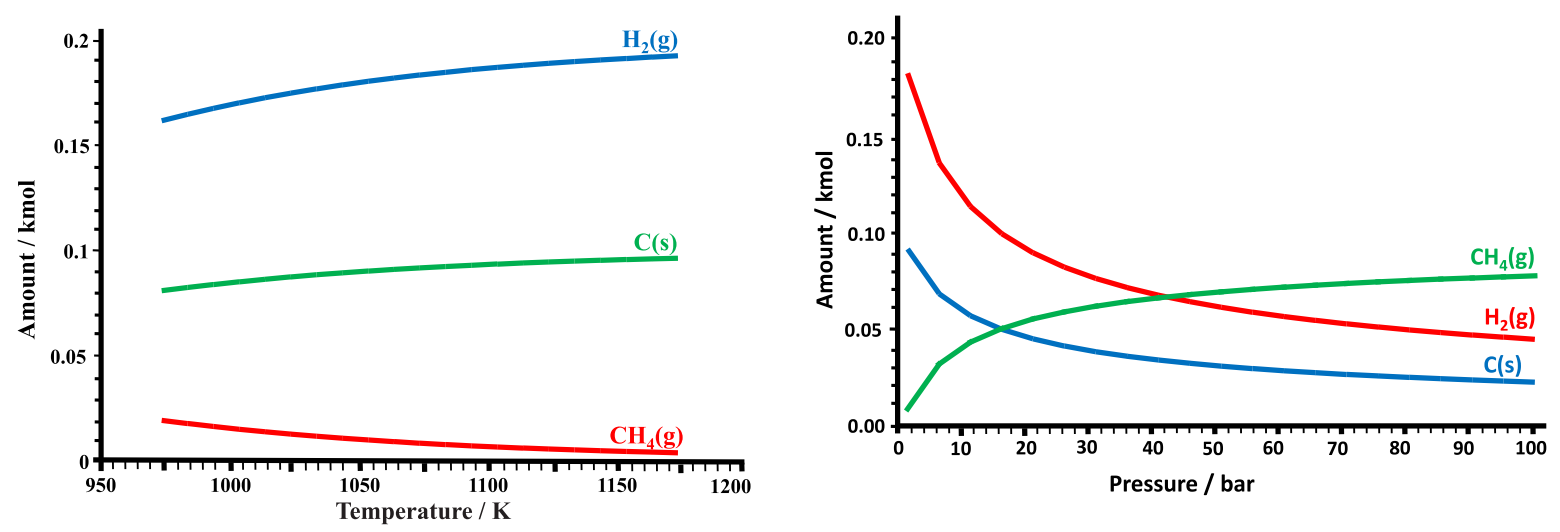

Figure 2: (a) Effect of temperature on equilibrium composition for the cracking of methane at molten tin interface at 1 bar (b) Effect of pressure on equilibrium composition for the cracking of methane at molten tin interface at $800{ }^{\circ} \mathrm{C}$

Figure $3 \mathrm{a}$ and Figure $3 \mathrm{~b}$ show the effects of temperature and pressure, respectively on equilibrium composition for the reaction of methane with dissolved oxygen in molten tin at 1 bar and $800{ }^{\circ} \mathrm{C}$, respectively for a $[\mathrm{O}]_{S_{n}}: \mathrm{CH}_{4}$ of 1:1. The equilibrium amounts of hydrogen and carbon monoxide increased with increasing temperature in the range 973-1173 $\mathrm{K}$ but decreased with increasing pressure in the range 1 - 100 bar investigated while the equilibrium amounts of the other species (carbon, carbon dioxide, steam, and methane) behaved 
otherwise. The equilibrium composition was predominantly hydrogen and carbon monoxide (syngas) in the temperature range $973-1173 \mathrm{~K}$ at 1 bar when $[0]_{S n}: \mathrm{CH}_{4}$ was $1: 1$.
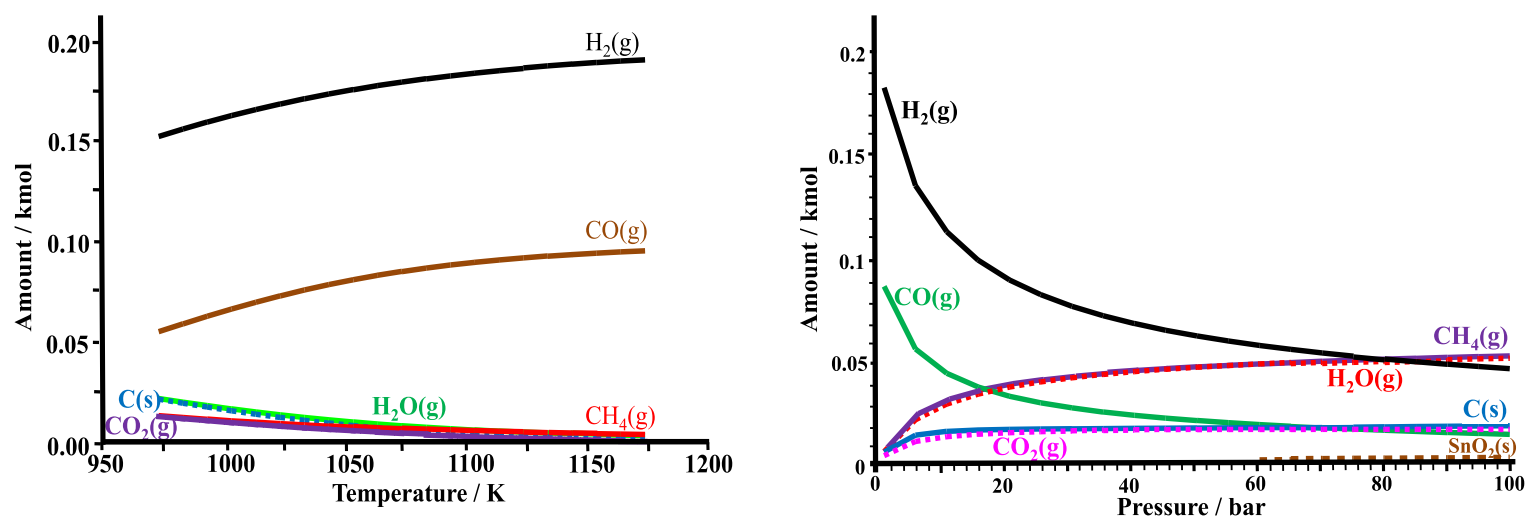

Figure 3: (a) Effect of temperature on equilibrium composition for the reaction of methane with dissolved oxygen in molten tin at 1 bar and $[\mathrm{O}]_{\mathrm{Sn}}: \mathrm{CH}_{4}$ of $1: 1$ (b) Effect of pressure on equilibrium composition for the reaction of methane with dissolved oxygen in molten tin at $800{ }^{\circ} \mathrm{C}$ and $[\mathrm{O}]_{\mathrm{Sn}}: \mathrm{CH}_{4}$ of $1: 1$

(a)

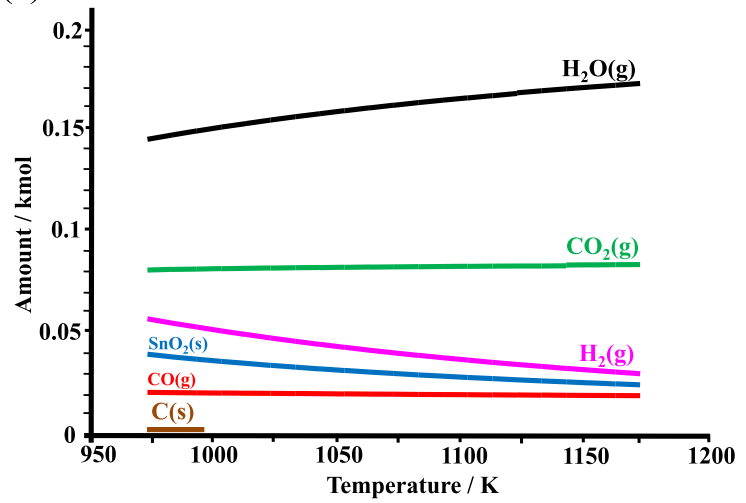

(b)

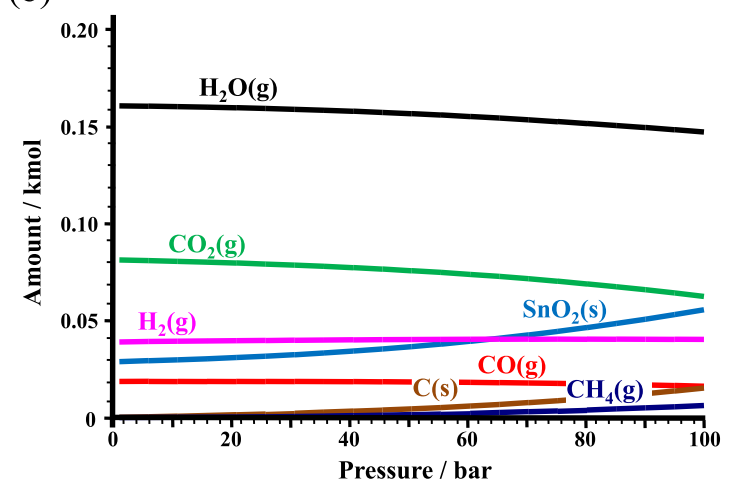

Figure 4: (a) Effect of temperature on equilibrium composition for the reaction of methane with dissolved oxygen in molten tin at 1 bar and $[\mathrm{O}]_{\mathrm{Sn}}: \mathrm{CH}_{4}$ of $4: 1$ (b) Effect of pressure on equilibrium composition for the reaction of methane with dissolved oxygen in molten tin at $800{ }^{\circ} \mathrm{C}$ and $[\mathrm{O}]_{\mathrm{Sn}}: \mathrm{CH}_{4}$ of $4: 1$

Figure $4 \mathrm{a}$ and Figure $4 \mathrm{~b}$ show the effects of temperature and pressure, respectively on the equilibrium composition for the reaction of methane with dissolved oxygen in molten tin at 1 bar and $800{ }^{\circ} \mathrm{C}$, respectively for a $[\mathrm{O}]_{S_{n}}: \mathrm{CH}_{4}$ of $4: 1$. The equilibrium amounts of steam and carbon dioxide increased with increasing temperature in the range $973-1173 \mathrm{~K}$ but decreased with increasing pressure in the range 1 - 100 bar investigated while the equilibrium amounts of the other species (carbon, carbon monoxide, hydrogen and tin dioxide) behaved otherwise. The equilibrium composition was predominantly steam and carbon dioxide in the temperature range $973-1173 \mathrm{~K}$ at 1 bar when $[\mathrm{O}]_{\mathrm{Sn}}: \mathrm{CH}_{4}$ was $4: 1$.

Figure 5 shows the effect of initial amount of dissolved oxygen in molten tin on equilibrium composition for the reaction of $0.1 \mathrm{kmol}$ of carbon with dissolved oxygen in molten tin at 1 bar and $800{ }^{\circ} \mathrm{C}$. At $[O]_{S n}: C$ of $1: 1$, the prevailing reaction was the partial oxidation of carbon to carbon monoxide while at $[O]_{S_{n}}: C$ of $2: 1$, the prevailing reaction was the total oxidation of carbon to carbon dioxide. 


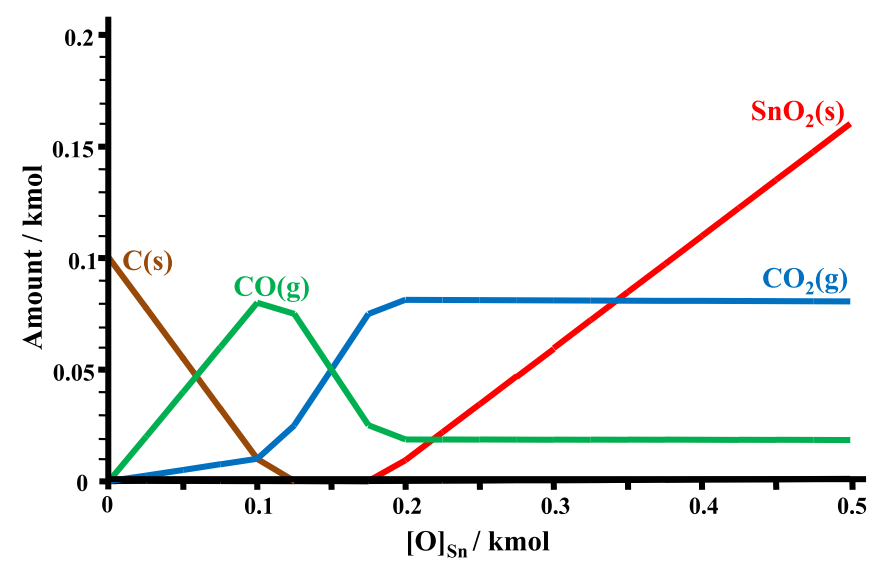

Figure 5: Effect of initial amount of dissolved oxygen in molten tin on the equilibrium composition for the reaction of carbon with dissolved oxygen at $800{ }^{\circ} \mathrm{C}$ and 1 bar.

Figure 6a shows the effect of temperature on equilibrium composition for the reaction of carbon with dissolved oxygen in molten tin at 1 bar and $[O]_{S_{n}}: C$ of $1: 1$ while

Figure $6 \mathrm{~b}$ shows the effect of pressure on equilibrium composition for the reaction of carbon with dissolved oxygen in molten tin at $800{ }^{\circ} \mathrm{C}$ and $[O]_{S n}: C$ of $1: 1$. At $[O]_{S n}: C$ of $1: 1$, temperature range of $973-1173 \mathrm{~K}$ and 1 bar the

(a)

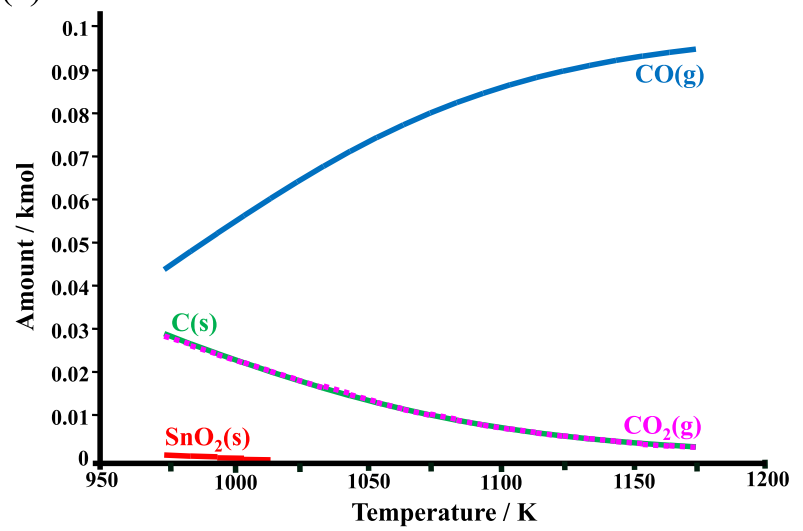

equilibrium composition was predominantly carbon monoxide while the amount of $\mathrm{CO}$ at 800 ${ }^{\circ} \mathrm{C}$ decreased with increasing pressure. However, at $[0]_{S n}: C$ of $2: 1$, temperature range of $973-$ $1173 \mathrm{~K}$ and 1 bar the equilibrium composition was mainly carbon dioxide as shown in Figure 7a while at $[O]_{S n}: C$ of $2: 1$ and $800{ }^{\circ} \mathrm{C}$, the amount of $\mathrm{CO}_{2}$ decreased with increasing pressure as shown in Figure $7 \mathrm{~b}$.

(b)

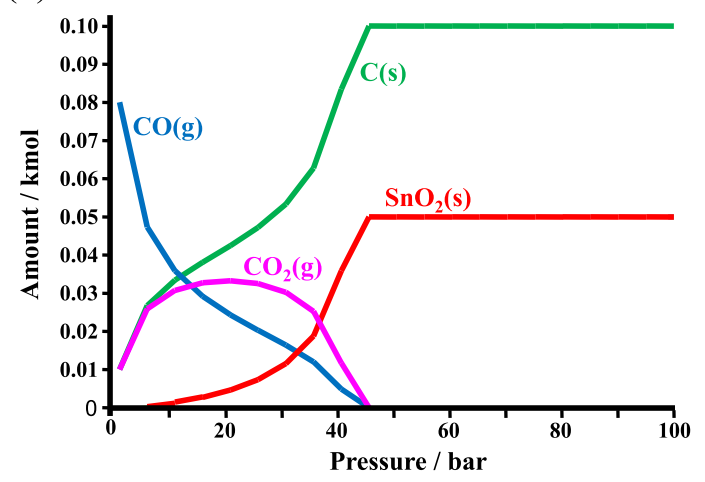

Figure 6: (a) Effect of temperature on equilibrium composition for the reaction of carbon with dissolved oxygen in molten tin at 1 bar and $[O]_{S_{n}}: C$ of 1:1 (b) Effect of pressure on equilibrium composition for the reaction of carbon with dissolved oxygen in molten tin at $800{ }^{\circ} \mathrm{C}$ and $[O]_{S n}: C$ of $1: 1$ 

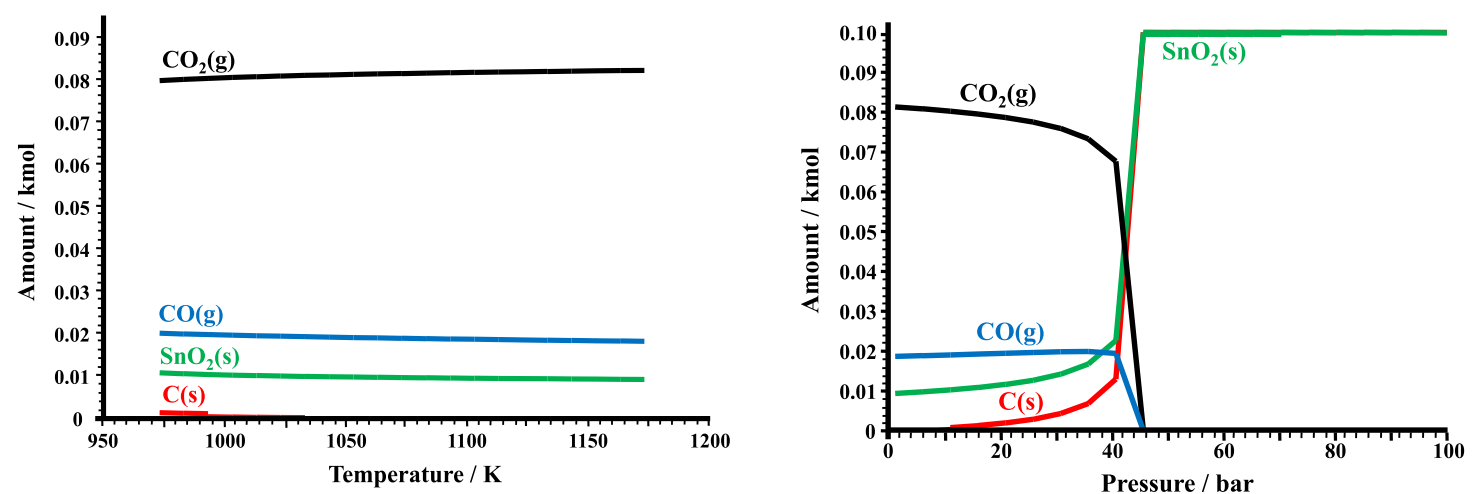

Figure 7: (a) Effect of temperature on equilibrium composition for the reaction of carbon with dissolved oxygen in molten tin at 1 bar and $[O]_{S_{n}}: C$ of $2: 1$ (b) Effect of pressure on equilibrium composition for the reaction of carbon with dissolved oxygen in molten tin at $800{ }^{\circ} \mathrm{C}$ and $[O]_{S n}: C$ of $2: 1$

\section{Equilibrium Compositions for $\mathrm{SnO}_{2}$ essential to also determine the effects of Reactions with Methane and Carbon temperature, pressure and initial amount of tin \\ As previously mentioned, tin oxide could be formed at the anode of the $\mathrm{Sn}_{(l)}$-SOFC, so it was oxide on equilibrium compositions for the reactions of tin dioxide with methane and carbon.}

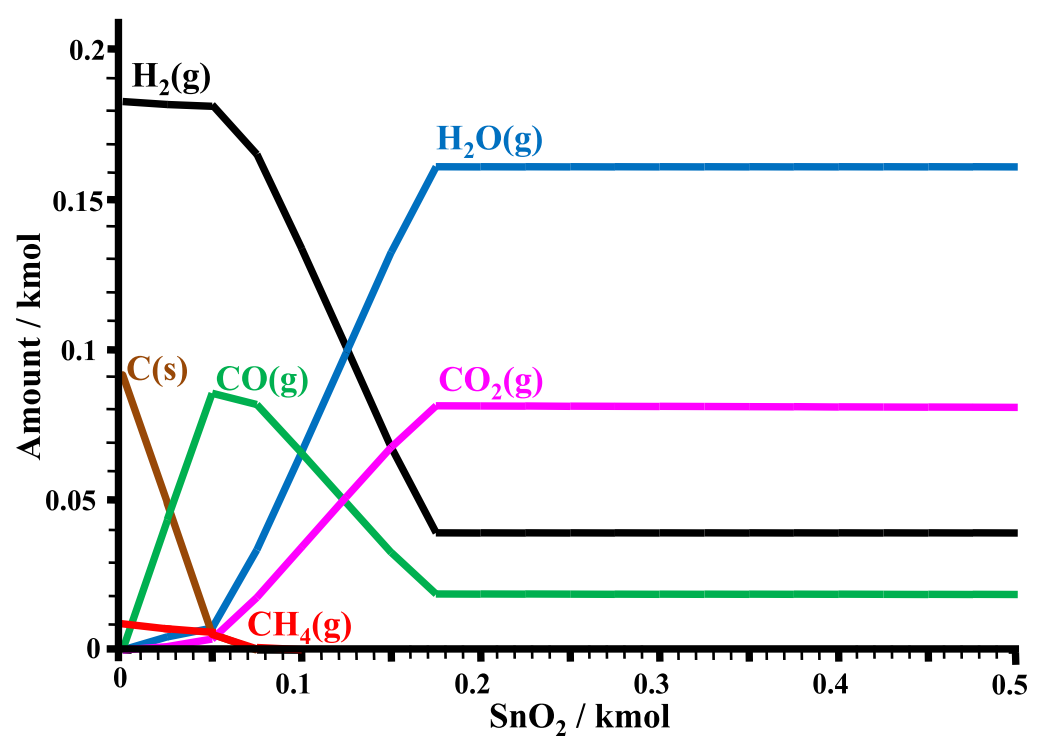

Figure 8: Effect of initial amount of $\mathrm{SnO}_{2}$ on the equilibrium composition for the reaction of $\mathrm{CH}_{4}$ with

$$
\mathrm{SnO}_{2} \text { at } 800^{\circ} \mathrm{C} \text { and } 1 \mathrm{bar}
$$

Figure 8 depicts the effect of the initial amount of tin oxide in molten tin on the reaction of 0.1 kmol of methane with tin dioxide at 1 bar and $800{ }^{\circ} \mathrm{C}$. Similar to the reaction of methane with dissolved oxygen in molten tin; the prevailing reaction at near-zero concentration of dissolved oxygen is the cracking of methane to carbon and hydrogen, at $\mathrm{SnO}_{2}: \mathrm{CH}_{4}$ of $1: 2$ is the partial oxidation of methane to carbon monoxide and hydrogen, and at $\mathrm{SnO}_{2}: \mathrm{CH}_{4}$ of 2:1 is the total oxidation of methane to carbon dioxide and steam. 
(a)

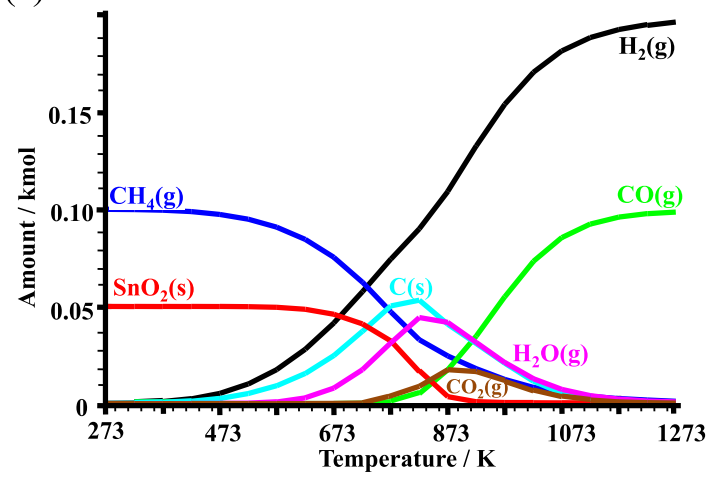

(b)

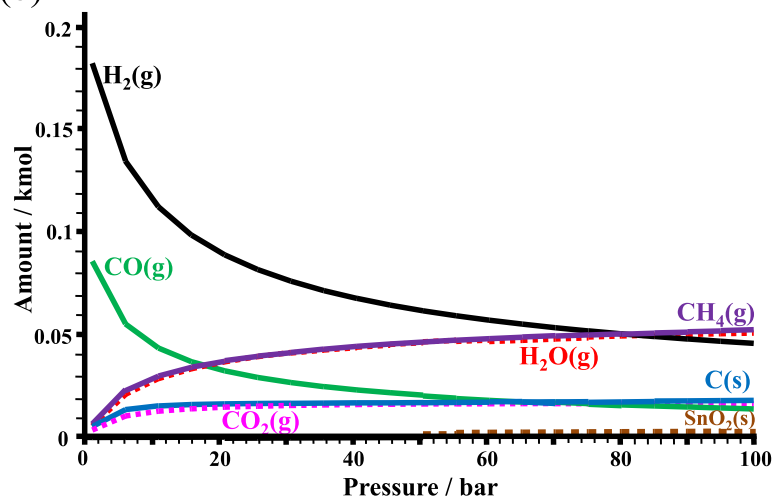

Figure 9: (a) Effect of temperature on equilibrium composition for the reaction of methane with tin dioxide in molten tin at 1 bar and $\mathrm{SnO}_{2}: \mathrm{CH}_{4}$ of $1: 2$ (b) Effect of pressure on equilibrium composition for the reaction of methane with tin dioxide in molten tin at $800{ }^{\circ} \mathrm{C}$ and $\mathrm{SnO}_{2}: \mathrm{CH}_{4}$ of $1: 2$

Figure 9a shows the effects of temperature on the equilibrium composition for the reaction of methane with tin dioxide in molten tin at 1 bar and $\mathrm{SnO}_{2}: \mathrm{CH}_{4}$ of $1: 2$ while Figure $9 \mathrm{~b}$ shows the effect of pressure on the equilibrium composition for the reaction of methane with tin dioxide in molten tin at $800{ }^{\circ} \mathrm{C}$ and $\mathrm{SnO}_{2}: \mathrm{CH}_{4}$ of 1:2. The equilibrium amounts of carbon monoxide and hydrogen increased with increasing temperature in the range $273-1273 \mathrm{~K}$ but decreased with increasing pressure in the range $1-100$ bar studied. At 1 bar, the equilibrium amounts of the other species (carbon, carbon monoxide, carbon dioxide, steam, tin dioxide and methane) decreased with increasing temperature in the range $973-1273 \mathrm{~K}$ but at $800{ }^{\circ} \mathrm{C}$, they increased with increasing pressure in the range $1-10$ bar investigated. The predominant species in the equilibrium composition were carbon monoxide and hydrogen, and consequently the prevailing reaction was methane reforming, at $973-1273$ $\mathrm{K}$ and 1 bar when $\mathrm{SnO}_{2}: \mathrm{CH}_{4}$ was 1:2. (a)

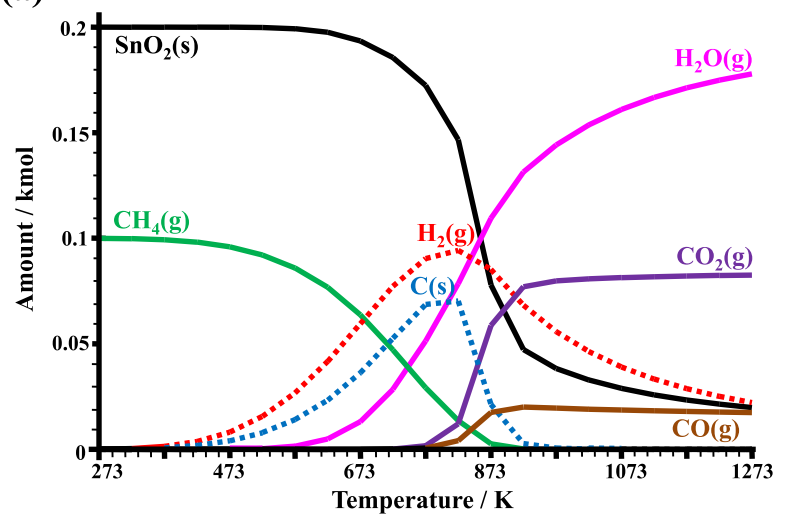

(b)

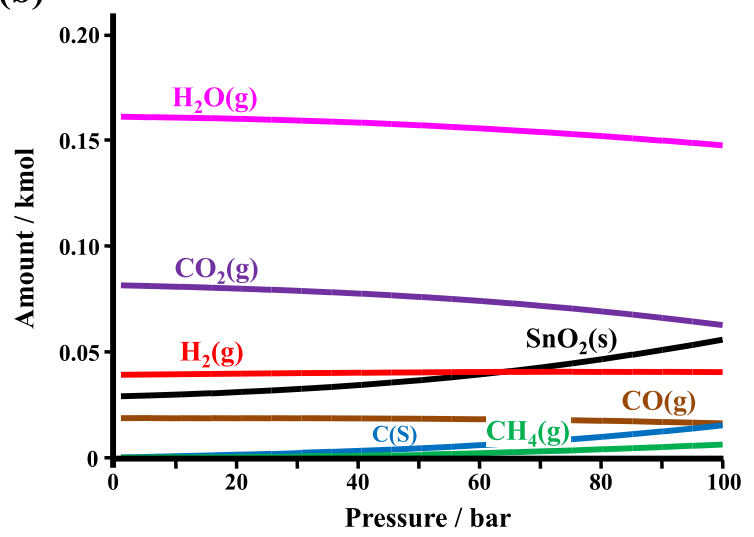

Figure 10: (a) Effect of temperature on equilibrium composition for the reaction of methane with tin dioxide in molten tin at 1 bar and $\mathrm{SnO}_{2}: \mathrm{CH}_{4}$ of 2:1 (b) Effect of pressure on equilibrium composition for the reaction of methane with tin dioxide in molten tin at $800{ }^{\circ} \mathrm{C}$ and $\mathrm{SnO}_{2}: \mathrm{CH}_{4}$ of $2: 1$ 


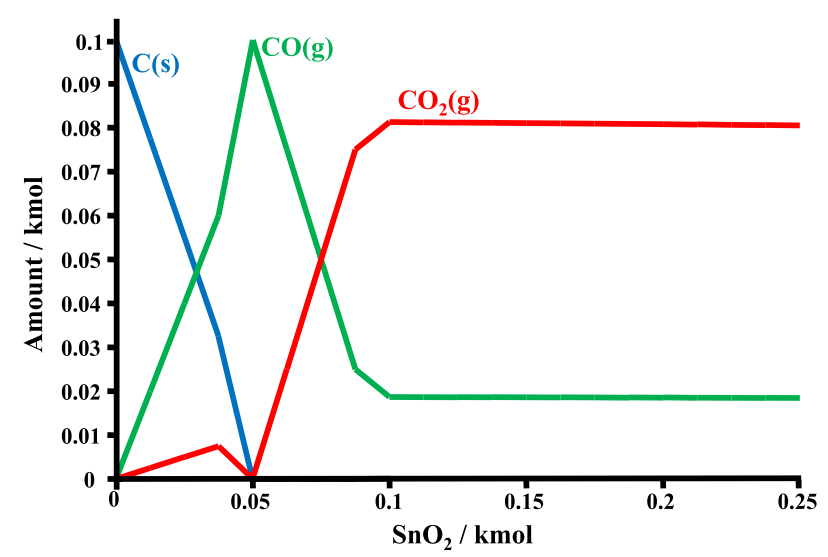

Figure 11: Effect of initial amount of $\mathrm{SnO}_{2}$ on the equilibrium composition for the reaction of carbon with $\mathrm{SnO}_{2}$ at $800^{\circ} \mathrm{C}$ and 1 bar

Figure 10a shows the effects of temperature on the equilibrium composition for the reaction of methane with tin dioxide in molten tin at 1 bar and $\mathrm{SnO}_{2}: \mathrm{CH}_{4}$ of 2:1 while Figure 10b shows the effect of pressure on the equilibrium composition for the reaction of methane with tin dioxide in molten tin at $800{ }^{\circ} \mathrm{C}$ and $\mathrm{SnO}_{2}: \mathrm{CH}_{4}$ of 2:1. The equilibrium amounts of carbon dioxide and steam increased with increasing temperature in the range $273-1273 \mathrm{~K}$ but decreased with increasing pressure in the range 1 - 100 bar considered. The predominant species in the equilibrium composition were carbon dioxide and steam, and consequently the prevailing reaction was the total oxidation of, at
$973-1273 \mathrm{~K}$ and 1 bar when $\mathrm{SnO}_{2}: \mathrm{CH}_{4}$ was 2:1.

Figure 11 shows the effect of the initial amount of tin oxide in molten tin on the equilibrium composition for the reaction of $0.1 \mathrm{kmol}$ of carbon with tin dioxide at 1 bar and $800{ }^{\circ} \mathrm{C}$. Analogous to the reaction of carbon with dissolved oxygen in molten tin, the prevailing reaction at $\mathrm{SnO}_{2}: \mathrm{C}$ of $1: 2$ is the partial oxidation of carbon to carbon monoxide while at $\mathrm{SnO}_{2}: \mathrm{C}$ of $1: 1$ is the total oxidation of carbon to carbon dioxide.
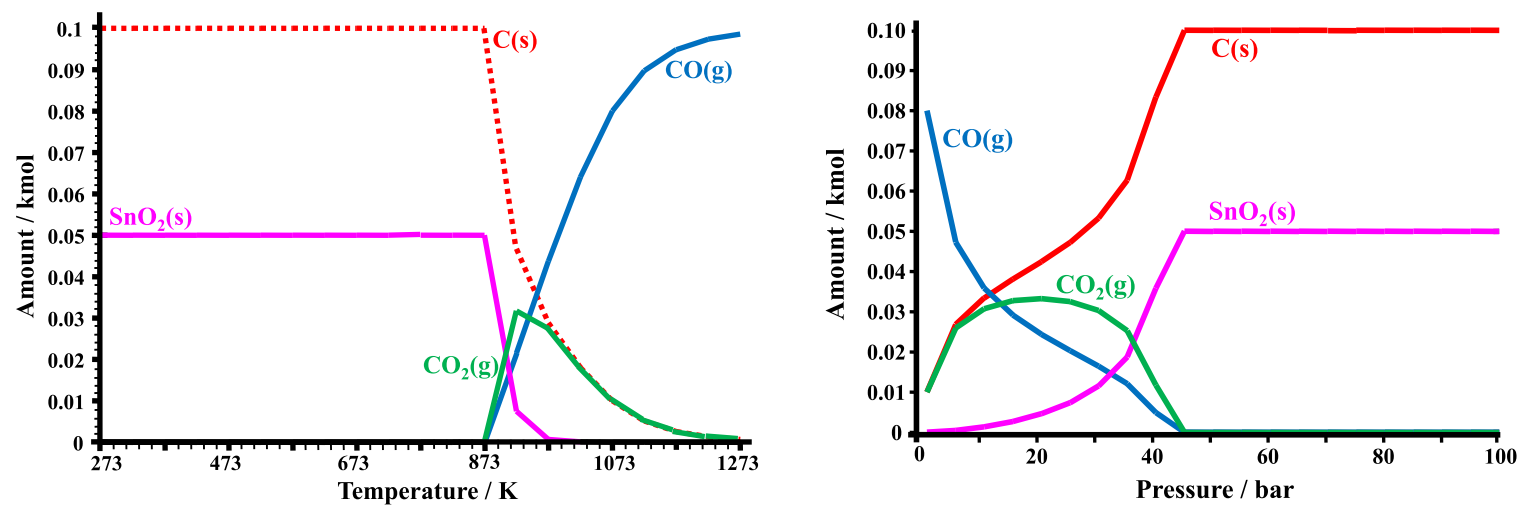

Figure 12: (a) Effect of temperature on equilibrium composition for the reaction of carbon with tin dioxide in molten tin at 1 bar and $\mathrm{SnO}_{2}: \mathrm{C}$ of 1:2 (b) Effect of pressure on equilibrium composition for the reaction of carbon with tin dioxide in molten tin at $800{ }^{\circ} \mathrm{C}$ and $\mathrm{SnO}_{2}: \mathrm{C}$ of $1: 2$ 
Figure 12a shows the effect of temperature on equilibrium composition for the reaction of carbon with tin dioxide in molten tin at 1 bar and $\mathrm{SnO}_{2}: \mathrm{C}$ of $1: 2$ while Figure $12 \mathrm{~b}$ shows the effect of pressure on equilibrium composition for the reaction of carbon with tin dioxide in molten tin at $800{ }^{\circ} \mathrm{C}$ and $\mathrm{SnO}_{2}: \mathrm{C}$ of 1:2. The CO concentration increased with increasing temperature but decreased with increasing pressure. At $\mathrm{SnO}_{2}: \mathrm{C}$ of 1:2, temperature range of $973-1173 \mathrm{~K}$ and 1 bar the equilibrium composition was majorly carbon monoxide and consequently the prevailing reaction was the partial oxidation of carbon.
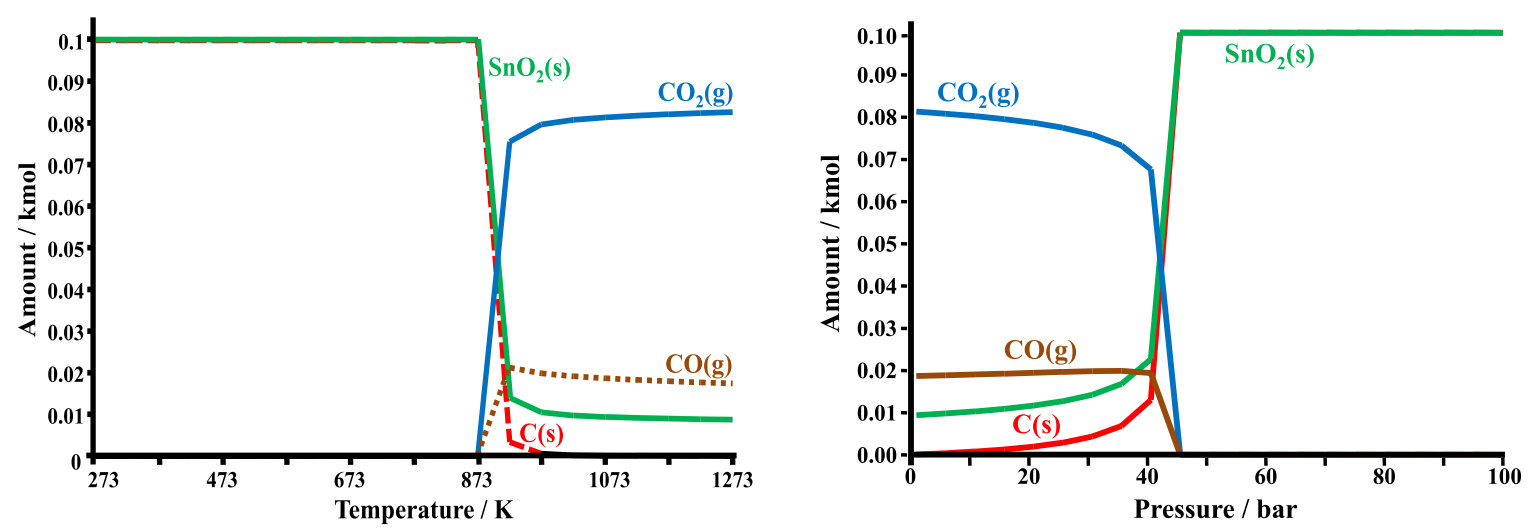

Figure 13: (a) Effect of temperature on equilibrium composition for reaction of carbon with tin dioxide in molten tin at $1 \mathrm{bar}$ and $\mathrm{SnO}_{2}: \mathrm{C}$ of 1:1 (b) Effect of pressure on equilibrium composition for the reaction of carbon with tin dioxide in molten tin at $800{ }^{\circ} \mathrm{C}$ and $\mathrm{SnO}_{2}: \mathrm{C}$ of $1: 1$

Figure 13a show the temperature dependence of equilibrium composition for the reaction of carbon with tin dioxide in molten tin at 1 bar and $\mathrm{SnO}_{2}: \mathrm{C}$ of $1: 1$ while Figure $13 \mathrm{~b}$ shows the pressure dependence of equilibrium composition for the reaction of carbon with tin dioxide in molten tin at $800{ }^{\circ} \mathrm{C}$ and $\mathrm{SnO}_{2}: \mathrm{C}$ of $1: 1$. At $\mathrm{SnO}_{2}: \mathrm{C}$ of $1: 1$, temperature range of $973-1173$ $\mathrm{K}$ and pressure of 1 bar the equilibrium composition was mainly carbon dioxide and so the prevailing reaction was the total oxidation of carbon. The $\mathrm{CO}_{2}$ concentration increased with increasing temperature but decreased with increasing pressure, showing that high temperatures and low pressures favour the total oxidation of carbon by $\mathrm{SnO}_{2}$.

\section{Conclusions}

Depending on the ratio $\left[\mathrm{O}_{S_{n}}: \mathrm{CH}_{4}\right.$ or $\mathrm{SnO}_{2}: \mathrm{CH}_{4}$, at 1 bar and $973-1173 \mathrm{~K}$, the prevailing reaction of methane at a molten tin anode may be cracking, reforming or total oxidation. Likewise, the prevailing reaction of carbon at a molten tin anode may be the partial or total oxidation depending on the ratio $[\mathrm{O}]_{\mathrm{Sn}}: \mathrm{C}$ or $\mathrm{SnO}_{2}: \mathrm{C}$ at 1 bar and $973-1173 \mathrm{~K}$. The equilibrium composition was mainly hydrogen and carbon in the temperature range $973-1173 \mathrm{~K}$ at 1 bar when $[\mathrm{O}]_{S n}$ or $\mathrm{SnO}_{2}$ was zero, and the prevailing reaction at the molten tin anode was the cracking of methane. The equilibrium composition was predominantly hydrogen and carbon monoxide (syngas) in the temperature range $973-1173 \mathrm{~K}$ at 1 bar when $[\mathrm{O}]_{\mathrm{Sn}_{n}}: \mathrm{CH}_{4}$ was $1: 1$ or $\mathrm{SnO}_{2}: \mathrm{CH}_{4}$ was 1:2 while the equilibrium composition was majorly carbon dioxide and steam in the temperature range 973 - $1173 \mathrm{~K}$ at 1 bar when $[O]_{S n}: \mathrm{CH}_{4}$ was $4: 1$ or $\mathrm{SnO}_{2}: \mathrm{CH}_{4}$ was 2:1. The equilibrium composition was predominantly carbon monoxide in the temperature range $973-1173$ $\mathrm{K}$ at 1 bar when $[O]_{S n}: C$ was $1: 1$ or $\mathrm{SnO}_{2}: \mathrm{C}$ was $1: 2$ while the equilibrium composition was mainly carbon dioxide in the temperature range $973-1173 \mathrm{~K}$ at 1 bar when $[O]_{S_{n}: C}$ was $2: 1$ or $\mathrm{SnO}_{2}: \mathrm{C}$ was $1: 1$. 


\section{Acknowledgements}

The authors thank the Petroleum Technology Development Fund, Nigeria for a studentship for Oluseye Agbede at Imperial College London, UK.

\section{References}

Abernathy, H., Gemmen, R., Gerdes, K., Koslowske, M. \& Tao, T. (2011) Basic properties of a liquid tin anode solid oxide fuel cell. J. Power Sources, 196 (10), 4564-4572

Andres, R. J., Gregg, J. S., Losey, L., Marland, G. \& Boden, T. A. (2011) Monthly, global emissions of carbon dioxide from fossil fuel consumption. Tellus B, 63 (3), 309-327.

Annamalai, K. \& Puri, I.K. (2002) Advanced Thermodynamics Engineering. Boca Raton, CRC Press

Barin, I., Knacke, O. \& Kubaschewski, O. (1977) Thermochemical Properties of Inorganic Substances, Berlin, Springer-Verlag.

Barin, I. (1993): Thermochemical Data of Pure Substances, Part I, Weinheim, VCH Verlags Gesellschaft.

Barin, I. (1993): Thermochemical Data of Pure Substances, Part II, Weinheim, VCH Verlags Gesellschaft.

Beér, J. M. (2007) High efficiency electric power generation: The environmental role. Prog. Energy Combust. Sci, 33 (2), 107-134.

Binnewies, M. \& Milke, E. (2002) Thermochemical Data of Elements and Compounds, $2^{\text {nd }}$ ed., Weinheim. Wiley-VCH.

Brett, D.J.L, Alan Atkinson, A., Brandon, N.P., Stephen J. \& Skinnerd, S.J. (2008) Intermediate temperature solid oxide fuel cells, Chem. Soc. Rev., 37, 1568-1578.

Chase M.W., Davies, C.A., Downey, J.R., Frurip, D.J., McDonald, R.A., \& Syverud, A.N.
(1985) JANAF Thermochemical Tables, $3^{\text {rd }}$ ed., J. Phys. Chem. Ref. Data, Vol. 14, Suppl. 1.

Frenkel, M., Kabo, G. J., Marsh, K. N., Roganov, G. N., \& Wilhoit, R. C. (1994) Thermodynamics of Organic Compounds in the Gas State, Vol. 1, Texas, Thermodynamic Research Centre.

Giddey, S., Badwal, S. P. S., Kulkarni, A. \& Munnings, C. (2012) A comprehensive review of direct carbon fuel cell technology. Prog. Energy and Comb. Sc., 38 (3), 360-399.

Gorte, R. J., Kim, H. \& Vohs, J. M. (2002) Novel SOFC anodes for the direct electrochemical oxidation of hydrocarbon. $J$. power sources, 106, 10-15.

Gurvich, L.V., Veitz, I.V., \& Alcock, C.B. (1989) Thermodynamic Properties of Individual Substances, $4^{\text {th }}$ ed., Vol. 1, New York, Hemisphere Publishing Corporation.

Glushko, V.P. (1994) Thermocenter of the Russian Academy of Sciences, IVTAN Association, Izhorskaya 13/19, 127412, Moscow, Russia

Holladay, J.D., Hu, J., King, D.L. \& Wang, Y. (2009) An overview of hydrogen production technologies, Catal. Today, 139, 244-260.

IPCC (2005) IPCC Special Report on Carbon Dioxide Capture and Storage. Prepared by Working Group III of the Intergovernmental Panel on Climate Change [Metz, B., Davidson, O., de Coninck, H. C., Loos, M. and Meyer, L. A. (eds.)]. Cambridge University Press, Cambridge, United Kingdom and New York, NY, USA, 442 pp.

Jacob, K.T. (2011) A New Type of SOFC for Conversion of High Temperature Heat to Electricity without Carnot Limitation. ECS Trans., 35 (1), 573-582.

Jayakumar, A., Vohs, J.M. \& Gorte, R.J. (2010) Molten-Metal Electrodes for Solid Oxide Fuel Cells. Ind. Eng. Chem. Res., 49 (21), 1023710241. 
Jayakumar, A., Lee, S., Hornes, A., Vohs, J.M. \& Gorte, R.J. (2010) A Comparison of Molten $\mathrm{Sn}$ and Bi for Solid Oxide Fuel Cell Anodes.J. Electrochem. Soc., 157 (3), B365-B369.

Knacke O., Kubaschewski O., \& Hesselman K., (1991) Thermochemical properties of Inorganic Substances, $2^{\text {nd }}$ ed., Berlin, Springer-Verlag.

Kurokawa, H., Sholklapper, T. Z., Jacobson, C. P., De Jonghe, L. C. \& Visco, S. J. (2007) Ceria Nanocoating for Sulfur Tolerant Ni-Based Anodes of Solid Oxide Fuel Cells. Electrochem. Solid-State Lett., 10 (9), B135-B138.

Labarbera, M., Fedkin, M. \& Lvov, S. (2011) Liquid Tin-Lead Anode Solid Oxide Fuel Cell Fueled by Coal. ECS Trans., 35 (1), 2725-2734.

Landolt, B. (1999) Thermodynamic Properties of Inorganic Material, Scientific Group Thermodata Europe (SGTE), Springer-Verlag, Berlin-Heidelberg.

Lunsford, J. H. (2000) Catalytic conversion of methane to more useful chemicals and fuels: a challenge for the 21st century. Catal. Today, 63, 165-174.

Matsuzaki, Y. \& Yasuda, I. (2000) The poisoning effect of sulfur-containing impurity gas on a SOFC anode: Part I. Dependence on temperature, time, and impurity concentration. Solid State Ionics, 132 (3-4), 261-269.

McBride, B.J. Gordon, S. \& Reno, M.A. (1993) Thermodynamic Data for Fifty Reference Elements. National Aeronautics and Space Administration. Report number: NASA-TP3287

Minh, N. Q. (2004) Solid oxide fuel cell technology-features and applications. Solid State Ionics, 174 (1-4), 271-277.

Nikolla, E., Schwank, J. \& Linic, S. (2009) Direct Electrochemical Oxidation of Hydrocarbon Fuels on SOFCs: Improved Carbon Tolerance of Ni Alloy Anodes. $J$. Electrochem. Soc., 156 (11), B1312-B1316.
Offer, G. J., Mermelstein, J., Brightman, E. \& Brandon, N. P. (2009) Thermodynamics and Kinetics of the Interaction of Carbon and Sulfur with Solid Oxide fuel Cell Anodes. J. Am. Ceram. Soc., 92, 763-780.

Ormerod, R.M. (2003). Solid Oxide Fuel Cells. Chem. Soc. Rev., 32, 17-28.

Otsuka, S., Sano, T. \& Kozuka, Z. (1981) Activities of oxygen in liquid $\mathrm{Bi}, \mathrm{Sn}$, and $\mathrm{Ge}$ from electrochemical measurements. Metall. Mater. Trans B, 12, 427-433.

Patnaik, P. (2003) Handbook of Inorganic Chemicals, New York, McGraw-Hill.

Ramachandran, R. \& Menon, R. K. (1998) An overview of industrial uses of hydrogen. Int. J. Hydrogen Energy, 23, 593-598.

Sarantaridis, D., Chater, R. J. \& Atkinson, A. (2008) Changes in physical and mechanical properties of SOFC Ni-YSZ composites caused by redox cycling. $J$ Electrochem Soc., 155 (5), B467-B472.

Song, C. (2002) Fuel processing for lowtemperature and high-temperature fuel cells: Challenges, and opportunities for sustainable development in the 21 st century. Catal. Today, 77 (1-2), 17-49.

Tao, T. (2005) Introduction of Liquid Anode/Solid Oxide Electrolyte Fuel Cell and Its Direct Energy Conversion Using Waste Plastics: Singhal, S.C. \& Mizusaki, J. (eds.) Solid Oxide Fuel Cells IX: The Electrochemical Society Proceedings, 99-19, Pennington, NJ, Electrochemical Society, pp 353-362.

Tao, T., Bateman, L., Bentley, J. \& Slaney, M. (2007) Liquid Tin Anode Solid Oxide Fuel Cell for Direct Carbonaceous Fuel Conversion. ECS Trans., 5 (1), 463-472.

Tao, T., McPhee, W. A., Koslowske, M. T., Bateman, L. S., Slaney, M. J. \& Bentley, J. (2008) Advancement in Liquid Tin Anode Solid Oxide Fuel Cell Technology. ECS Trans., 12 (1), 681-690. 
Van Der Laan, G. P. \& Beenackers, A. A. C. M. (1999) Kinetics and Selectivity of the FischerTropsch Synthesis: A Literature Review. Catal. Rev., 41, 255-318.

World Energy Council (2013) World Energy Resources 2013 Survey [Online: pdf] Available from:http://www.worldenergy.org/wp-
content/uploads/2013/09/Complete_WER_2013 Survey.pdf [Last accessed: 12th February 2014].

Wu, D. W. \& Wang, R. Z. (2006) Combined cooling, heating and power: A review. Prog. Energy and Comb. Sc., 32 (5-6), 459-495. 